UDC 373.2.091.321

DOI https://doi.org/10.32840/1992-5786.2021.79.1.4

\author{
O. L. Bukhalo \\ Candidate of Pedagogical Sciences, \\ Associate Professor at Preschool Education Department \\ Mariupol State University
}

A. O. Yemelyanenko

Bachelor Student of the 4th year of studying Mariupol State University

\title{
THE VALUE OF EVALUATORY STATEMENTS OF KINDERGARTEN TEACHERS IN THE PERSONAL DEVELOPMENT OF SENIOR PRESCHOOLERS
}

The article reveals the essence of the concept of "evaluative statement of the teacher", which is understood as the activities carried out by the subjects, aimed at establishing an assessment of objects, during which the realization of human values of a person to reality with which he interacts is taken place. This problem is relevant for preschool education and directly for the effective personal development of preschool children. Preschool childhood is the age of the most rapid physical and mental development of the child, the initial formation of qualities and properties that are necessary for a person throughout life.

The teacher's evaluation activity has the following components: the study of the pupil's personality, his behavior and attitudes; forecasting the impact of assessments on the child's behavior, personal development; evaluation of own methods of evaluation activity and making evaluation decisions; planning of evaluative statements; implementation of evaluation decisions in the course of pedagogical interaction; correction of evaluative statements. The object of evaluation may be the manifestations of behavior and activities of the preschooler in various spheres of life: actions, reasoning, expressions, process and results of activities, relationships, personal qualities and properties, and so on.

The following types of evaluative statements due to the nature of relationships and interactions in the system "adult-child" are highlighted. They are destructive (containing critical thoughts about the child, his personal qualities, behavioral acts, actions and their results), restrictive (using the ratio of actions and results of the child with a standard, "sample", a rule of conduct that is well known to the teacher and "as if" should be known to the child), restructive (supportive statements of child's behavior and his various activities), developmental (involve not only a positive assessment of qualities, actions, educational achievements of the child, but also the possibility of further acquisition, enrichment of subjective experience, and on its basis to improve the child).

Key words: teacher's evaluative statements, preschooler's personal development, evaluation activity, pedagogical evaluation, types of evaluative statements, destructive statements, restrictive statements, restructive statements and constructive statements.

Formulation of the problem. The modern system of preschool education is developing as an open, variable system focused on the provision of educational services to families with preschool children. The problems of providing new approaches to the organization of educational activities of preschool education, its interaction with the family and primary school are brought to the fore; the emphasis is on the effectiveness of socialization processes, individualization of personal development of preschoolers. In this regard, we need a professional, who is able in the changing socio-economic conditions, the general situation in the preschool education system in the country, to assess pedagogical situations and choose the best options for organizing the educational process, calculate socially significant educational outcomes, provide quality of preschool education.

In addition, one of the priority areas of preschool education is the development of the child's person- ality, which involves the formation of competencies, initiative, independence, curiosity, ability to creative self-expression, as well as involving children in universal values. That is, preschool education is designed to implement the public order - the preparation of the younger generation for socially-oriented, active creative life. However, in the real practice of preschool education, its methodological support lags far behind, and thus complicates the implementation of social expectations, which can be explained by the peculiarities of preschool age.

The problem of the evaluative activity of the teacher and its influence on the process of personal development of the preschool child is important for preschool pedagogy. It is the evaluative statements of the teacher and other adults that mediate the manifestation of positive emotions in the process and result of actions; contribute to the development of responsibility, initiative, the emergence of personal 
significance, diverse motivation; provide in the environment of the preschool institution conditions for the full realization of the abilities and potential of the child, i.e. is an incentive for further personal development of the preschooler.

Analysis of recent research and publications. Scientists, referring to the concept of "personal development" (K. Bondarevskaya, V. Zaitsev, N. Sergeev, V. Serikov, etc.), consider it as self-awareness, self-improvement, self-development, development of creative potential of the individual, creative activity. The main approaches to the problem of personal development in preschool age were studied by S. Izyumova, R. Craig, O. Orlov, K. Rogers, D. Shvetsov, substantiating the need to support the child during this age period.

The analysis of scientific sources showed that the evaluation and evaluation statements, evaluation activities of the teacher are studied mainly during school (Sh. Amonashvili, B. Ananiev, V. Polonsky, etc.). The problem of pedagogical assessment and evaluation, in its various aspects, has been studied in the works of leading psychologists and teachers (S. Rubinstein. V. Blonsky, D. Elkonin, Z. Kalmykova, Y Babansky, N. Talizina, O. Leontiev, G. Schukina , M. Skatkin, I. Lerner, B. Ananiev, O. Luria, I. Yakimanskaya, L. Vygotsky, L. Bozhovich, A. Markova). They define evaluation as a process of "correlation of the process or result of activity with the standard set in the task" (Sh. Amonashvili), as action (O. Wegner), as activity (S. Beznosov), as a set of special skills (L. Mnatsakanyan) and as a function (K. Platonov).

The purpose of the article is to define the concept of "evaluative statements of the kindergarten teacher" and to reveal their impact on the personal development of older preschool children.

Presenting main material. Preschool childhood is the period from birth to school, it is the age of the most rapid physical and mental development of the child, the initial formation of physical and mental qualities necessary for a person throughout life, qualities and properties that make him a person. Analysis of scientific research gives an understanding of preschool childhood as a special stage in the formation of personality [1, 2]. It is proved that during this period in the process of personal development mental properties, qualities and abilities are formed and differentiated, which have value and determine the course of further development (O. Belkin, L. Bozhovych, L. Vygotsky, P. Halperin, O. Zaporozhets, I. Zimnya, O. Leontiev, S. Rubinstein, D. Elkonin).

Humanization of interaction is the most important direction of creating a developmental environment in kindergarten: changing the nature of communication, the relationship between adult and child. The change of the tactics of pedagogical assessment of the child's behavior and activities, its various manifestations that determine emotional well-being; the child's attitude to himself, the world around him and "himself in this world" is important. The child is able to reveal himself as a person, fully show his creative initiative and independence in the event that he feels safe, comfortable and pleasant to act; he clearly understands the assessments, the requirements for him, where he is valued as he is and celebrates his successes and achievements. It is impossible to organize pedagogical activity without assessment, because assessment is one of the main components of this activity, its indicator of effectiveness.

Evaluation activity means the activity carried out by the subjects, it is aimed at establishing evaluation in relation to the objects, during which the realization of a person's value attitude to the reality with which he interacts is taken place. The result of evaluation activities is evaluation as a quantitative and qualitative expression of the evaluation attitude. In this case, evaluation can be seen as a process of forming an idea, statement, opinion about something, and evaluation is a form, a "shell" of the evaluation result, as "an opinion about the quality, dignity, value of someone or something" [3]. According to N. Seleznyov, pedagogical assessment has a socially specific nature, as it is dictated by "the needs of society in a particular type of personality and is expressed in the form of pedagogical thoughts or marks in accordance with socially set standards" [4, p.53].

In the organization of the process of personal development of children in the environment of kindergarten, an important role is played by the evaluative activity of the teacher, who performs a number of important functions: control (evaluation is manifested in the requirements of society); organizational (assessment is considered as a condition for certain actions of the child and the results of his activities); diagnostic (involves recognition, definition, a brief conclusion about the "essential qualities" of the child's personality: needs, capabilities, abilities, dynamics of its diverse development); indicative (expressed in the setting for the formation of a preschool child positive motives for various activities, readiness for self-control; stimulating self-development (promotes the formation of self-awareness and adequate self-esteem of behavior and activities of children).

The evaluation activity of the teacher has a certain logic and is carried out through the consistent implementation of the following evaluation actions: the study of the child's personality, his behavior and attitudes (assessment of the level of development and current status of children); forecasting the impact of assessments on the child's behavior, personal development; evaluation of own methods of evaluation activity and making evaluation decisions; planning of evaluative statements; implementation of evaluation decisions in the course of pedagogical interaction (interpersonal interaction); correction of evaluative statements. 
The results of the analysis of psychological and pedagogical literature allowed to distinguish various forms of assessment of students: partial assessments, as an emotional attitude expressed in words, gestures, facial expressions of the teacher, which means consent, approval, remarks, condemnation, reproach; meaningful assessments, as expressions of evaluative opinions obtained as a result of the process of correlation of the process or the result of activities with the planned standard; assessments are presented in the form of marks, which are recorded in the documents, reflecting the general level of student's achievement (knowledge, skills and abilities) or the level of identification of certain actions, qualities, properties of preschoolers [4].

According to the specifics of preschool education, the teacher's assessment activities should be carried out in the form of meaningful assessments of the level of development and current status of the preschool child, i.e. assessment of educational achievements should not occur in comparison with other children, but only in relation to his own achievements. The object of teacher's evaluation can be external manifestations of behavior and activities of the preschooler in various spheres of life: actions, reasoning, expressions, process and results of productive children's activities, relationships, personal qualities and properties, states and more. In this case, the teacher's assessment will be in different variations: from emotional attitudes to different verbal and nonverbal reactions. Verbal manifestation in the attitude and expressions of the teacher, and nonverbal - in facial expressions, or appropriate behavior (approving nod, sharp hand movements or, for example, "threats" with the index finger) or "label" in a symbolic form (a number, a picture of the sun).

The preschool child is in great emotional dependence on the educator, because the need for positive emotions of a significant adult largely determines the child's behavior. It is important for a child that an adult not only notices, but also gives a positive assessment, praises his actions. The support and approval of adults, even minor successes, can meet a child's need for love, emotional support, respect and recognition. And if an adult constantly makes remarks, critically evaluates, emphasizes the incompetence or inability of the child, he loses interest in this case and he seeks to avoid it.

Under the influence of adult assessments, the child often begins to pay attention to the process and result of his actions, strives to achieve the desired socially and personally significant results. Evaluative statements become a regulator of the child's actions, under their influence the ability to act consciously develops, volitional processes and character are formed. The senior preschooler is concerned not only with the assessment of specific skills, but also with the assessment of him as a person. The child seeks to ensure that the adult's assessments coin- cide with his own, so it is important to understand the essence of the assessment requirements in order to see himself "as if from the side", consciously adhere to the norms, i.e. manage his behavior, and build his relationships with others.

In the conditions of educational process in kindergarten the following problems in realization of pedagogical estimation are observed: complexity of allocation of a subject of pedagogical estimation and estimation criteria; weakness of the evaluation criterion; the use of school assessment technologies or assessment methods that have questionable scientific and practical value. The results of such an assessment do not always adequately reflect the real picture of the development of a preschool child, which can disorient teachers and parents in organizing interaction with children.

The specificity of preschool age is that all mental processes are very mobile and plastic, and personal development, the disclosure of the potential of the child, largely depends on what conditions are created by the teacher and parents. Assessment activities are carried out in the course of pedagogical interaction with children, in the process of which there is a projection of the value attitude of the teacher to other participants in the educational process. In this regard, it makes sense to highlight the evaluative statements of teachers, formulated within the pedagogical interaction in various spheres of child's life. It is important that pedagogical assessment directly or indirectly determines the emotional and value, socio-personal, cognitive, aesthetic development of the child, preserves his individuality in the educational environment of the preschool institution.

Conditionally we can distinguish the following types of pedagogical statements, due to the nature of the relationship and interaction in the system "adult-child": destructive, restrictive, restructuring and constructive.

Destructive type of pedagogical assessment deals with evaluative statements of the teacher, which contain critical thoughts about the child, his personal qualities, behavioral acts, actions and his results. For example, "Again, you've done everything wrong", "Everything because of you", "What is it?", "I see that you are cheating on me", "All children your age are already drawing well, and you even don't hold a pencil well!"; "Well, who do you look like?"; "Great job, but next time I'm expecting more from you!" etc. Such statements of the teacher are accompanied by exclamatory irritated intonation and brightly expressed "aggressive" facial expressions and pantomime. Destructive statements lead to a significant limitation of independence in cognition of the world and in practical actions, i.e. the child's reluctance to express himself in various activities, withdrawal from activities, communication and interaction; avoidance of assessments; lower self-esteem. Self-doubt leads to the development of inferiority complex, and as a consequence, irritability, resentment, aggression, distrust of others. 
Restrictive type of pedagogical assessment deals with evaluative statements using the ratio of actions and results of the child with the standard, "sample", a rule of conduct that is well known to the teacher and "as if" should be known to the child. In most cases, assessment is carried out in accordance with the development of individual qualities, without taking into account a holistic approach to the process of personal development of the preschooler. Examples of restrictive statements are: "If you try harder, we will put your work on display (we will allow you to speak in front of your parents at the party)", "I think, it is your fault. Think about what...", "I know, it's all because you ..."; "Today you did well, but ...". This type of pedagogical assessment limits the child's actions to a conditional framework, the expressiveness of children's manifestations, leads to the extinction of initiative, independence, which reduces emotional tone and satisfaction with the actions performed. The child in the process of pedagogical interaction seeks to identify and keep in mind the multiple limitations (norms, requirements) of the educator, in order to obtain positive assessments of the adult.

Restructive (supportive) type of pedagogical assessment deals with evaluative statements that are supportive of the child's behavior and various activities ("You are good, smart, kind, and responsible", "I'm very happy for you! You've drawn these figures so well", "Great!", "I liked how you did today". In most cases, such an assessment is accompanied by open, supportive adult behavior, praise, approval. This assessment is aimed at ensuring the emotional well-being of the child, his positive well-being, self-confidence, the realization of the child's capabilities. Although this type of assessment provides the processes necessary to maintain a sense of comfort of the child, it does not always determine the prospects and tactics of his personal development.

In the developmental type the assessment is carried out taking into account the interests of the child and the prospects for his further development. Evaluative statements of the teacher provide not only a positive assessment of the qualities, actions, educational achievements of the child, but also the possibility of further acquisition, enrichment of subjective experience, and on its basis, improvement, selfchange of the child. Examples of constructive evaluative statements are the following: "What a good child you are! How well you did! You didn't succeed until recently, and today, finally, you succeeded without my help. Do you know why did you succeed?"; "What a wonderful work. Maybe you can teach other children this?". This type of expressions gives a lot to the child's self-confidence, a stable positive attitude towards himself, openness to the outside world. The child, being in a state of emotional comfort and well-being, will develop more optimally, that is to make decisions quickly; to make attempts to act, to show initiative, to show independence in various kinds of children's activity, creative activity, without being afraid of a possibility of failure. If his expectations or that of an adult are not met, the child will try again and again to do what is given with some difficulty.

In our opinion, a real pedagogical assessment should be aimed at the activity and personal components of the child's activity. The assessment should equally present the evaluative statements of the teacher about the process and results of activities, as well as the personal qualities of children. The adult must attach importance to the personal manifestations of the child, his manifestations as a subject, as an individual must be evaluated.

Such types of evaluative statements are manifested in various areas of pedagogical interaction in the regulated and unregulated (free) activities of children in the educational process of preschool education. The nature of evaluative statements affects the change in behavior and activities of students, which in turn determine the effectiveness or the "developmental effect" of the environment in which the child is.

The socio-psychological nature of pedagogical assessment is manifested in the fact that the assessment may be different in its effectiveness, depending on the socio-pedagogical situation in which it is carried out. Pedagogical evaluative statements offered in different situations may have different meanings and with different levels of probability to meet the needs of the child. Pedagogical assessments, which have the greatest "valence" in this situation and provide the highest probability of personal development of the child, his self-realization are predominant in the construction of pedagogical interaction in the preschool institution.

Conclusions and suggestions. Thus, the evaluative activity of the teacher is an integral part of education and training; it is a process that has its own role and identification. We have considered the evaluative statements of teachers, which are manifested in the process of pedagogical interaction as a basis for personal development of a preschool child. The assessment should be equally focused on the formulation of the teacher's statements about the personal and activity successes of the child. Pedagogical assessment provides systematic information; design and transformation of the educational process aimed at education, training and development of preschoolers.

\section{References:}

1. Кононко О.Л. Психологічні основи особистісного становлення дошкільника : автореф. дис. ... докт. психол. наук: 19.00.07. Київ, 2001. 37 с.

2. Психічний розвиток дитини-дошкільника: метод. посіб. С.Є. Кулачківська, Т. О. Піроженко, Л. Г. Подоляк. К.: Світоч, 2004. 75 с.

3. Кельнер С.С. Оцінювання знань як стимул розвитку. Шкільному психологу все для роботи. № 9. 2012. С. 23-28.

4. Селезнев Н. В. Роль педагогической оценки. Педагогика. 1996. № 10. С. 52-55. 


\section{Бухало О. Л., Ємельяненко А. О. Значення оцінних висловлювань вихователів у особистісному розвитку старших дошкільників}

У статті розкрито сутність поняття «оцінне висловлювання педагога», яке розуміється як діяльність, що здійснюється суб'єктами, спрямована на встановлення оцінки відносно об'єктів, у процесі якої відбувається реалізація ціннісного ставлення людини до дійсності, з якою вона взаємодіє. Означена проблема $є$ актуальною для дошкільної освіти та безпосередньо для ефективного особистісного розвитку дітей дошкільного віку. Дошкільне дитинство - ие вік найстрімкішого фрізичного і психічного розвитку дитини, первинного формування якостей $і$ властивостей, що необхідні людині протягом усього подальшого життя.

Оцінна діяльність педагога має такі складники, як: вивчення особистості вихования, його поведінки і відносин; прогнозування впливу оцінок на поведінку дитини, особистий розвиток; оцінка власних способів оцінної діяльності й ухвалення оцінних рішень; планування оцінних висловлювань; реалізація оцінних рішень у процесі педагогічної взаємодії; корекція оцінних висловлювань. Об'єктом оцінювання можуть бути прояви поведінки і діяльності дошкільника в різних сфрерах життєдіяльності: дії, міркування, вислови, процес і результати видів діяльності, відносини, особисті якості і властивості тощо.

Виділено такі типи оцінних висловлювань, зумовлених характером відносин і взаємодії в системі «дорослий - дитина»: деструктивні (містять критичні думки про вихования, його особисті якості, поведінкові акти, дії і їх результати), обмежувальні (здійснюються за допомогою співвідношення дій і результатів дитини з еталоном, «зразком», правилом поведінки, який добре відомий педагогу $i$ «ніби» повинен бути відомий і вихованцю), реструктивний (висловлювання мають підтримуючий характер поведінки і різних видів діяльності дитини), розвивальні (передбачають не тільки позитивну оцінку якостей, дій, освітніх досягнень дитини, але і можливість подальшого набуття, збагачення суб'єктивного досвіду, а на його основі вдосконалення дитини).

Ключові слова: оцінні висловлювання педагога, особистісний розвиток дошкільника, оцінна діяльність, педагогічна оцінка, типи оцінних висловлювань, деструктивні висловлювання, обмежувальні висловлювання, реструктивні висловлювання і конструктивні висловлювання. 